\title{
Micro Credit and Women Empowerment: A Study on Grameen Bank's Strategy of Poverty Alleviation
}

\author{
Mohammed Thanvir Ahmed Chowdhury ${ }^{1}$, Musa. Halima Begum ${ }^{2}$, \\ Md. Ridwan Reza ${ }^{3}$, Tahrima Chowdhury Jannath ${ }^{4}$
}

${ }^{1,2}$ Senior Lecturer (Sociology), Department of Business Administration, Leading University, Bangladesh

${ }^{3}$ Senior Lecturer, Department of Business Administration, Leading University, Bangladesh

${ }^{4}$ MBA, Department of Business Administration, Leading University, Sylhet, Bangladesh

\begin{abstract}
Generally, it is held that, Women economic participation is positively related to their status. It is assumed that participation changes woman's power relationship and hence her status in the family, and thus a woman having no such access will have relatively low power and status. Relatively argued, women experience hunger and poverty in much more intensive ways than men. If one of the family members has to starve, it is an unwritten law that it has to be the mother. That is why women were targeted in the center point of micro credit program. However, the stagnation in the impact of micro credit on income may have serious implication for the success of micro finance institution and their long term sustainability and therefore the question deserves serious attention from researchers. The above concerns are related mostly to the long term impact of micro credit. Thereby we were intended to see the structures which dictate dependence press on these women. And if the gains they have made in income and assets are to be sustained, the control they have negotiated over their lives is to be maintained. In this regard, we want to see how women can build their empowerment and what Grameen Bank can do to strengthen them for poverty alleviation.
\end{abstract}

Key Words: Micro Credit, Women Empowerment, Poverty Alleviation

JEL Classification Code: I32; E51

\section{INTRODUCTION}

In rural Bangladesh, women have little or no access to the formal employment market nor do they have the necessary credit to engage in income generating activities. The attractive feature of micro credit is its ability to address the credit needs of the poor. This credit generates work for women in the informal sector. Thus micro credit institutions in Bangladesh (like Grameen Bank) have developed strategies for providing collateral free loans to the poor and asset less households. Although poverty alleviation has featured as a priority development goal of successive governments, nearly half of the population of the country continues to live below the poverty threshold. Therefore, there is hardly any controversy about the great urgency of pursuing the objective of poverty reduction in the shortest possible time. Provision of micro credit has been widely recognized as an 
important instrument for achieving thus objectives. Our study focused the debate on the strategy of poverty alleviation as well as the impact of micro credit program on the women of rural areas. And we hope our study may contribute to investigate the socioeconomic condition of rural women in future.

Bangladesh achieved independence in 1971. The situation worsened further when a devastating famine hits Bangladesh in 1974. Against this backdrop a number of humanitarian organizations set up relief and rehabilitation camps throughout Bangladesh. These organizations came to be known as non-Governmental organization or NGOs. Their programs of rehabilitation in a devastated economy gained popularity and the NGOs are present in every remote corner of the country performing vivid of functions ranging from relief for the disaster stricken and destitute population to provide training for empowerment of women and entrepreneurship to alleviate poverty. The BRAC, PROSHIKA, ASA, GRAMEEN BANK are the leading NGOs of present Bangladesh and GRAMEEN BANK is mostly renowned among them due to the winning of novel peace prize in 2006 by Dr. Yunus and Grameen bank together. Traditional banks in Bangladesh are gender biased and do not want to lend money to women. In Bangladesh, if woman even rich women want to borrow money from a bank, the manager will ask; did you discuss this with your husband? And if she answers yes, the manager will say, is he supportive of your proposal? If the answer is still yes, he will say, would you please bring your husband along so that we can discuss it with him?

But no manager would ever dream of asking a prospective male borrower whether he has discussed the idea of a loan with his wife and whether he would like to bring his wife along to discuss the proposal. Even suggesting this would be an insult! So it is not by chance that prior to Grameen, women constituted less than 1 percent of all the borrowers in Bangladesh put together. To Dr. Yunus it was clear that the banking system itself was gender biased. Thus no longer question of avoiding gender bias, there was now a development reason to favor women. The more Yunus got involved, the more he realized that credit given to women brought about changes faster than when given to men (Dr. Yunus, Banker to the poor, 1998). The Grameen Bank's extension of credit to the rural poor has lead to the creation of opportunities for self employment (Yunus, 1982). The female participants in the Grameen Bank program earn cash incomes and contribute to the total family budget on a regular basis. A Bangladesh institute of bank management study documented that women borrowers increased their family income by about $72 \%$ due to availability of Grameen bank credits (Quasim et al, 1985)

The land, scale of poverty, powerlessness and gender subordination in rural Bangladesh forms the contextual basis for Grameen bank and indeed the micro credit model in Bangladesh. The famine of 1974 provided the urgency for professor Md. Yunus to look for alternatives. He discovered that while the credit market was the scene of the most brutal exploitation of the poor (with high interest rates leading to persistent indebtedness, leading to forced sale of assets and destitution). It was also the arena where interventions were easiest for allowing the poor to break out of their cycle of poverty. The conventional banking structure however does not provide access to the poor because the poor can provide no collateral and because the overheads required for servicing loan become too high for the small size of loans that people required. Government loan programs for rural areas in turn get monopolized by the rich and powerful. Amongst the poor, women are even more discriminated against; because patriarchal norms ensures their exclusion from the facto ownership of assets and because the work that women generally engage in (home 
based) are not classified as economically productive. Hence the need for targeted collateral free credit for the poor and specifically poor women; hence the need for micro credit.

1.1 Micro Credit: A small amount of money used as a means of boosting income of the poor recipients.

1.1.2 Poverty: Poverty means number of people do not have the purchasing capacity to buy their survival basic needs such as a minimum level of food consumption, level of schooling, clothing and shelter.

1.1.3 Women Empowerment: Empowerment of women means recognizing women's contribution, enhancing their self respect and self dignity, controlling their own bodies \& resources like land and other property and freedom of speech \& choice.

\section{Objectives of the Study}

The broad objective of this study is to see the relationship between micro credit and women empowerment. More specific objectives of this research are as follows-

(a) To study the role of Grameen Bank on women empowerment;

(b) To evaluate Grameen Bank's strategy of poverty alleviation.

\section{SOME NOTEWORTHY LITERATURE}

Studies on Micro credit have been mostly evaluative in nature. Researchers have tried to examine the kind of impact Grameen Bank programs have had, especially on women borrowers. Generally, these studies provide descriptive data on gradual changes in the number of Grameen Bank memberships, amount of loans taken, income earned from loan money, household income, areas of investment, acceptance of dowry, outside participation, and women's status in the family.

One such study was conducted by Ghai (1984) who evaluated Grameen Bank's program at a very early stage of its establishment. He notes that

1. "Remarkable feature and strength of the project is the attention paid to women among the landless" (1984:17).

2. At the time of his writing female clients rose from $31 \%$ in 1980 to $46 \%$ in 1983 .

3. Ghai points out that, prior to becoming banks member, most of these women were beggars, agricultural laborers, maid servants or housewives. They had no access to resources which could improve their economic condition.

4. With loans from Grameen bank, they began investing in two major sectors, livestock and fisheries, and processing and manufacturing.

5. The earning opportunity for women has a clear impact on the division of labor between the spouses. While women borrowers can engage in making bamboo and cane products, husking rice or looking after a cow, husbands can complement the family income by selling processed rice, milk, meat, handicrafts and buying raw materials (Ghai, 1984).

6. Ghai also notes that, contrary to the popular belief that a women's participation in the process of earning incomes potentially creates tension in the family, it actually improves the relationship among the spouses and mothers-in-law. It also improves a wife's overall status in the household and in the local community" (Ghai, 1984:41).

In another study, Hossain (1984) specially focused on the extent of Grameen Bank's impact on poor women's employment and income as well as productivity. His primary source of data came from a sample survey among 612 randomly selected Grameen Bank borrowers conducted by the Bangladesh Institute for Development Studies (BIDS). 
1. Commenting on the socioeconomic background of the female borrowers, he mentions that majority (61\%) of the respondents belonged to an extremely impoverished group. At the time of applying for loans $65 \%$ of those women were unemployed and rest were domestic workers.

2. Hossain's study (1984) shows that the loan money enables female borrowers to add to the family budget. Their net yearly household income is estimated to be 6000 taka and their productive labor yields only 1.31 taka per hour which is $42 \%$ lower than the wage of male borrowers.

3. Hossain concludes: "considering that women have very few job opportunities, whatever little they earn contributes to the increasing household and per capita income (1984:21)."

Looking at socioeconomic status (SES) and mobility of the Grameen bank's female clients, measured by indicators such as increase in land ownership, income and gainful employment, Ahmed (1985) noted considerable changes in all these areas.

1. Thirty seven percent of the females $(\mathrm{N}=120)$ said that they owned some land, and fifty eight percent who had no income before earned some money after taking loans from the bank.

2. Furthermore, his study showed that while "entrepreneurial activities" increased by twenty-eight percent for these women, their housework decreased by forty percent. These are the result of investing Grameen Bank's loan money into income generating activities.

The review of studies done so far shows that research on Grameen Bank has focused on its performance, its success in accessing the landless rural poor, the recovery of credit, problems with rural village power structure and so forth. A very few have exclusively studied the impact credit has had on women's lives.

Ahmed (1985), among others, investigated whether borrowing from Grameen Bank has had any effects on woman's actual as well as perceived status.

1. He assumed that Grameen Bank woman participants would be more conscious than non-participants about the evil of dowry, repression, divorce, desertion, and violence against them, and consequently may more often support equal rights for men and women.

2. Ahmed's study reveals that, even though awareness about such issues is very high (81 to 100 percent) among the female borrowers, only 48 percent of them support equal rights.

3. However, he shows only 19 percent of the women in Ahmed's sample actually justify wife beating on the ground that it is a controlling mechanism for "disobedience, slowness in household chores and an attempted self-assertion as well as for feeding the 'sadistic' male ego" (Ahmed, 1985:14).

4. Apart from this minor exception, Ahmed found that overall there has been an improvement in the perceived status of the wives (measured by husband's attitude towards wife before and after she took a loan).

In a later study, Hossain (1986) also found that,

1. Grameen Bank credit has produced new employment among one-third of the female respondents (out of 534 females). Loans taken by females are mostly invested in such activities as cow, goat and poultry raising, paddy and pulse husking and trading, cattle fattening, peddling, grocery and stationary shops, and in traditional cottage industries such as handlooms weaving, mat and fish-net making. 
2. Even though the maximum of an individual loan is 5000 taka, Hossain's (1986) study shows that forty percent of the female members loans range between 1400-2500 taka. In comparison to men, women received $15 \%$ less money. He further mentions that a female member's loan amount as compared to that of a male was always less for most of the activities.

Islam-Rahman (1986), on the other hand, systematically documented the impact of Grameen Bank by comparing four groups of women: Grameen Bank female members who took loans over different periods of time, women from the same (project) village who had no access to Bank's credit, non-borrowers from two control villages (Tangail and Rangpur) where Grameen Bank did not operate, and non-borrowers from the project as well as from the control villages.

1. His expectation was that earnings gained through involvement in the Bank's program would bring about changes in the consumption pattern of food and clothing, family decision-making, and reproductive behavior of women. Grameen bank participants were expected to have an increased consciousness about the education of children and their job opportunities, and to oppose early marriage of their daughters.

2. The majority of the female clients in Islam-Rahman's (1986) study are from nuclear families. Only $25 \%$ have primary or little education. Their average landownership is only 2.5 acres.

3. Eleven percent of her sample are widowed or divorced and only four and one-half percent are unmarried, while the majorities (84\%) are married. Islam-Rahman reports that on all accounts Grameen bank borrowers are better off compared to other groups. Most of the females are found to be inexperienced in conducting their own entrepreneurial activities.

4. Islam-Rahman (1986) notes that $77.4 \%$ of the women themselves utilize almost $75 \%$ of the credit. In almost all cases there has been an increase in the incomes of Bank's borrowers. On the average, women contribute $38 \%$ to the total household income and this happened because very few of these women were previously generating an income.

5. On decisions about the purchase of food items, clothing, medical expenses, visiting relatives, and marriage of children, Islam-Rahman notes that even those who let their husbands manage their loan "are in a better situation than housewives in the male loaner group though they are less important than the active loaner women" (1986:68).

6. Female borrowers take a more active part in decision making compared to any other group.

To find out extent to which the Bank's efforts raise awareness among women, Atiur Rahman (1986) gathered data through a sample survey of female and male members from Rangpur, Tangail and Dhaka regions.

1. His findings show that $54 \%$ of the male and $81 \%$ of the female respondents learned to sign their names and in the process become aware of the necessity of education. A majority said they would provide higher education for their sons, while they agreed that girls should have some education.

2. Citing case studies from Rangpur and Patuakhali areas, Rahman mentions that women discovered strength in collective solidarity and not only challenged the traditional norms and values, but also fought against social injustices. Overall, members are aware of the disadvantages of purdha, dowry, superstition, as well as the benefits of sanitation, small family, late age at marriage, and group cooperationconditions that provide an opportunity to enhance their quality of life. 
3. However, as Grameen Bank's social development programs are at a formative stage, Rahman cautions about its impact: They have at least economic staying power, a precondition which normally does not exist among the other poor (1986:47).

The findings of Qazi Kholikuzzaman Ahmed (2007) from the study of socio economic impact of micro credit in Bangladesh is given below.

1. Only about $10 \%$ of all female respondents (numbering 2482) have said that they are in full control of running the economic activities undertaken using micro credit they received. The other $90 \%$ run them either in consultation with their husbands and other members of their respective families or they do not participate at all.

2. About $72 \%$ of the female respondents are now always or occasionally give more importance in family decision making compared to the situation before enrollment.

3. About $28 \%$ of the female respondents still face physical or mental torture from one or another member of the family, usually the husband. The intensity of torture has increased in the case of $60 \%$ of these respondents, while in the case of $40 \%$ it's about the same or somewhat less than before.

Dixon (1978: 15) argued that, "a woman earning half of the household income will likely have more bargaining power than the woman who earns none, even when total household earnings are the same." In developing countries survival of low income families may compel all members to engage in productive activities. In spite of little improvement in total household earnings a woman's status is likely to be affected by the increase in bargaining power as a result of her crucial contribution to family subsistence. Lee and Peterson (1983) have noted that when the wife's contribution becomes a valued resource for the welfare of the family, the wife will have more influence in decision making.

\subsection{The process of poverty alleviation through micro credit:}

Success of micro credit in poverty alleviation will depend on how far it can address the constraints faced by the poor households. The economic environment characterizing the poor consists of lack of ownership of productive assets and lack of adequate remunerative employment. Human capital endowment is a requisite for ensuring remunerative nonagricultural employment; but the literacy rate among the rural poor is low. Members from extreme poor households face disadvantages in the labor market in the form of gender segmentation and adverse terms of attached labour (Sen 1993). Manifestation of extreme poverty may take the form of malnutrition (Chowdhury 1992) and ill health which has a second round effect in perpetuating poverty.

Expansion of micro credit in Bangladesh and other South-East Asian countries has been rooted in the expectation that MC can help in the generation of self employment which can solve the problems of both unemployment and poverty in these densely populated developing countries. Poor households access to institutional finance is limited because of their inability to provide collateral. Poor households can improve their income through an increase in the labour force participation ratio, which is possible through women's involvement in income generating activities. The access to micro credit is expected to ease the constraints in the credit market and thereby create self employment and increase the productivity and earnings from self employment. The global commitment to micro credit as a vehicle for poverty reduction is evident from the aims of the forthcoming micro credit summit. In Bangladesh, there will be further expansion of these programs in response to their success in effectively targeting poor people and reducing their poverty. It is believe that programme expansion will strengthen the likelihood that structural constraints of economic, social and gender relations will be reduced. (Mustafa et al 1996 p. 20) 


\subsection{The overwhelming credit attraction:}

The safest way for NGOs to get away from total economic dependency on shrinking aid funds is to increase their share of revolving loan funds. Once these revolving loan funds have been lent to my target group and then repaid, they become an asset fully controlled by the NGOs. A real asset when it comes to future economic security and sustainability from the NGOs point of view. This then becomes the solution for the NGOs in their struggle for economic sustainability for their organization.

The description above reveals that almost all the major impact assessment studies obtained positive pictures of the impact of micro credit on income. However one should also examine the limitation of the performance of micro credit.

What we need is a systematic investigation into the question of whether women's participation in the Grameen bank and income derived from such participation are valued resources for decision-making power in the family. From the family sociological perspective, answers to this question with data from Bangladesh may help to strengthen the theoretical understanding of power in the family. Conversely, it may show the limitations of the application of such a theory to developing nations. From the larger perspective of a scientific discipline like sociology or family sociology, an attempt to test the general theories of the field is certainly important in itself. While it adds to the cumulative knowledge of the field in terms of enhancing a theory's generalize ability, it can also validate or modify specific components of a theory.

\section{Methodology}

In this study exploratory-analytical research design has been followed. It has been tried to explore the relationship between micro credit and women empowerment through Grameen Bank's strategy of poverty alleviation. Concerning the study area, at first Sylhet district is selected purposively. Secondly Mollargaon branch of Grameen bank is selected purposively as it is one of the biggest branches of Grameen bank in Sylhet. The required primary data for this study were collected from the above study area in July, 2011.

\section{Population and Sampling}

The total 3879 women participants of Grameen bank Mollargaon Branch are the population of this study. Stratified random sampling is used as a method to draw the sample size. At first the population is divided into four strata based on their joining date. Strata 1(0-5 years length of attachment with Grameen Bank), strata 2(6-10 years), strata $3(11-15$ years), strata $4(15+$ years $)$. Then total sample size ' $n$ ' is selected by using the following formula----

$$
\begin{aligned}
& \mathrm{n}=\mathrm{p} . \mathrm{q} z 2 / \mathrm{e} 2 \text {. deff } \quad \mathrm{n} \text { =sample size } \\
& \text { z2 =Two-sided normal variate } \\
& \text { value at } 95 \% \text { confidence level (1.96) } \\
& =0.5 \times 0.5(1.96) 2 /(0.10) 2 \times 1.5 \quad \text { deff }=\text { Design effect } \\
& =144
\end{aligned}
$$

Now to draw the sample size from each stratum, proportional allocation formula is used $\mathrm{ni}=\mathrm{n} / \mathrm{N} \times \mathrm{Ni}$

So, the total sample size $=n 1+n 2+n 3+n 4=69+34+26+15=144$ 
In this study, methodological triangulation (sample survey, case study) used. Firstly by using schedule questionnaire, information is collected from 144 respondents through sample survey method. And guide questionnaire is also used for case study to get in depth understanding of the respondents. The collected quantitative information is processed through SPSS program by using computer. To represent qualitative information several case studies have been made.

\section{Results AND Discussion}

Credit programs target credit to the rural poor- those who are functionally landless (owning less than half an acre of land) or having assets amounting to less than the value of an acre of medium quality land or engaging in wage labor for once livelihood. Since collateral is not required, credit program generally relying on the group mechanism, transfers risks of non repayment from the program to the group itself. The problem of asymmetrical information (program having limited information on borrowers) is resolved through selection of members by the group (screening out high risk borrowers) and through imposition of joint liability on the group. While individual borrowers receive loans, sanctions (in the form of suspension of new loans) are imposed on the collective group in the case of default by any individual borrower.

From the early days of the expansion of MFIs, the skeptics have put forward the views that the micro credit financed activities bring in a law return and micro credit cannot therefore be instrumental in raising household income. Given the law rate of return from most rural activities investment opportunities would soon be exhausted and the scope for further expansion of micro credit would be limited. Even though such evidences have not been established through rigorous quantitative research, skeptical views have been expressed in a number of newspaper report and in some case study based research paper.

From this study, it is viewed that among the 144 respondents aged woman have high frequency and in age group 45-49, highest amount of people $(21.5 \%)$ remains on that (Appendix Table 1). We see that among total population in our study area, $77.8 \%$ people are married, only $2.8 \%$ are unmarried, $5.6 \%$ divorce, $2.8 \%$ are separated and $11.15 \%$ are a widow. It can be said that maximum loan taker are married women (Appendix Table 2). Turning to religious status, we find 120 people (83.3\%) are Muslim and $16.7 \%$ people are Hindu. Hence we can say most of the respondents are Muslim who have been involved with Grameen bank's micro credit program in our study area (Appendix Table 3). Concerning the educational qualification, it reveals that more than fifty percent people $(53.5 \%)$ are illiterate. Twenty five percent respondents have primary education, $16 \%$ have secondary education, and only $5.6 \%$ have higher secondary education. So it is clear that most of the people are involved with micro credit program are illiterate (Appendix Table 4).

As regard this study, we see that 69 people out of $144(47.9 \%)$ are involved with micro credit program from 1-5 years. And the lowest 15 people $(10.4 \%)$ have attachment with Grameen bank for more than 15 years (Appendix Table 5). We found that $88.9 \%$ people have the house of their own and only $11.1 \%$ people have no house (Appendix Table 6). We see a large number of people (41.7\%) have the income between 4001-6000 taka. Only 1.4\% among the 144 people has income more than 10000 taka (Appendix Table 7). Our findings shows that 112 respondent out of 144 pay the installment from their business profit but sometimes it goes tougher and 32 female feel burden; that indicates they are unable to pay installment from the profit money (Appendix Table 8). We found that, from 
144 respondent $41 \%$ follow the family planning program and $56.3 \%$ respondent are not following this (Appendix Table 9).

Our study represents $36.1 \%$ family out of 144 respondents, husband plays headship role, in $32.6 \%$ family son plays headship role and in $22.2 \%$ family respondent herself plays headship role (Appendix Table 10). From the study, we found that 24 women out of 144 look after their property by themselves, 52 women said their husbands look after their property. And 68 women out of 144 replied their son look after their own property. So it is clear that very few member of micro credit look after their own property (Appendix Table 11). It can be said from the study, women who have the control over the property are only $16.7 \%$ of 144 women. And $36.1 \%$ replied their husband have the control over the property and the highest percentage $47.2 \%$ women said their son have the control over the property. Hence it is noticed that very few percentage of women have the control over the property (Appendix table 12). According to the respondent's view, 50.7\% respondent feel micro credit program is good, $29.9 \%$ respondent think micro credit activities are very good program. And 19.4\% respondent mentioned it is satisfactory to them (Appendix Table 13).

\section{Correlations Matrix}

\begin{tabular}{|c|c|c|c|c|c|c|c|}
\hline & & \begin{tabular}{|c|} 
Monthly \\
income of \\
responden \\
ts at \\
present
\end{tabular} & $\begin{array}{c}\text { Present } \\
\text { assets of } \\
\text { respondents }\end{array}$ & $\left|\begin{array}{c}\text { Educational } \\
\text { qualification } \\
\text { of } \\
\text { respondents }\end{array}\right|$ & $\begin{array}{c}\text { Duration } \\
\text { of } \\
\text { involveme } \\
\text { nt }\end{array}$ & $\begin{array}{l}\text { Amount of } \\
\text { loan taken }\end{array}$ & $\begin{array}{c}\text { Control } \\
\text { over loan }\end{array}$ \\
\hline \multirow{3}{*}{\begin{tabular}{|c|} 
Monthly income \\
of respondents \\
at present
\end{tabular}} & $\begin{array}{c}\text { Pearson } \\
\text { Correlation }\end{array}$ & 1 & .226 & .148 & .435 & .597 & .364 \\
\hline & Sig. (2-tailed) & . & .007 & .076 & .000 & .000 & .000 \\
\hline & $\mathrm{N}$ & 144 & 144 & 144 & 144 & 144 & 144 \\
\hline \multirow[t]{3}{*}{$\begin{array}{c}\text { Present assets of } \\
\text { respondents }\end{array}$} & $\begin{array}{c}\text { Pearson } \\
\text { Correlation }\end{array}$ & .226 & 7 & .087 & .116 & .306 & .194 \\
\hline & Sig. (2-tailed) & .007 & . & .302 & .166 & .000 & .020 \\
\hline & $\mathrm{N}$ & 144 & 144 & 144 & 144 & 144 & 144 \\
\hline \multirow[t]{3}{*}{\begin{tabular}{|c|} 
Educational \\
qualification of \\
respondents
\end{tabular}} & $\begin{array}{c}\text { Pearson } \\
\text { Correlation }\end{array}$ & .148 & .087 & 1 & -.251 & -.015 & -.106 \\
\hline & Sig. (2-tailed) & .076 & .302 & . & .002 & .861 & .205 \\
\hline & $\mathrm{N}$ & 144 & 144 & 144 & 144 & 144 & 144 \\
\hline \multirow[t]{3}{*}{$\begin{array}{c}\text { Duration of } \\
\text { involvement }\end{array}$} & $\begin{array}{c}\text { Pearson } \\
\text { Correlation } \\
\end{array}$ & .435 & .116 & -.251 & 1 & .373 & .373 \\
\hline & Sig. (2-tailed) & .000 & .166 & .002 & . & .000 & .000 \\
\hline & $\mathrm{N}$ & 144 & 144 & 144 & 144 & 144 & 144 \\
\hline \multirow[t]{3}{*}{$\begin{array}{c}\text { Amount of loan } \\
\text { taken }\end{array}$} & $\begin{array}{c}\text { Pearson } \\
\text { Correlation } \\
\end{array}$ & .597 & .306 & -.015 & .373 & 1 & .330 \\
\hline & Sig. (2-tailed) & .000 & .000 & .861 & .000 & . & .000 \\
\hline & $\mathrm{N}$ & 144 & 144 & 144 & 144 & 144 & 144 \\
\hline \multirow[t]{3}{*}{$\begin{array}{c}\text { Control over } \\
\text { loan } \\
\end{array}$} & $\begin{array}{c}\text { Pearson } \\
\text { Correlation } \\
\end{array}$ & .364 & .194 & -.106 & .373 & .330 & 1 \\
\hline & Sig. (2-tailed) & .000 & .020 & .205 & .000 & .000 & . \\
\hline & $\mathrm{N}$ & 144 & 144 & 144 & 144 & 144 & 144 \\
\hline
\end{tabular}

** Correlation is significant at the 0.01 level (2-tailed).

* Correlation is significant at the 0.05 level (2-tailed). 
Concerning the above correlation matrix, it can be said that, with the respondent's current monthly income, present assets of respondents, educational qualification, duration of involvement with micro credit, amount of loan taken and control over loan are positively correlated. With present assets of respondents, educational qualification, duration of involvement, amount of loan taken, and control over loan are positively correlated. With educational qualification, duration of involvement, amount of loan taken and control over loan are negatively correlated. With duration of involvement, amount of loan taken and control over the loan are positively correlated. Finally with amount of loan taken, control over loan is positively correlated.

Table: Current assets of respondents Vs Duration of involvement with micro credit

\begin{tabular}{|c|c|c|c|c|c|c|}
\hline & & $\begin{array}{r}\text { Duration } \\
\text { of involve } \\
\text { ment }\end{array}$ & & & & Total \\
\hline & & $1-5$ & $6-10$ & $11-15$ & $15+$ & \\
\hline \multirow{16}{*}{$\begin{array}{l}\text { Current assets } \\
\text { of respondents }\end{array}$} & House & 29 & 3 & & & 32 \\
\hline & Boat & & 1 & 3 & 4 & 8 \\
\hline & Shop & 2 & 2 & & & 4 \\
\hline & Wood business & 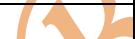 & 4 & 4 & & 8 \\
\hline & Raw materials & 4 & 7 & 4 & & 15 \\
\hline & Rice business & ( & 2 & 2 & 4 & 8 \\
\hline & Fish business & 1 & 3 & & & 4 \\
\hline & House+ rickshaw & (1) & 1 & & & 4 \\
\hline & House + cattle+ firming land & 2 & 7 & 4 & & 16 \\
\hline & House+ rickshaw + raw materials & & 2 & 7 & 6 & 15 \\
\hline & Polli phone & 4 & & & & 4 \\
\hline & House+ polli phone & 12 & & & & 12 \\
\hline & House+ boat & 1 & 2 & 1 & & 4 \\
\hline & House+ Cattle & 4 & & & & 4 \\
\hline & House+ Tractor & 4 & & & & 4 \\
\hline & others & & & 1 & 1 & 2 \\
\hline Total & C & 69 & 34 & 26 & 15 & 144 \\
\hline
\end{tabular}

Turning to the table above, we see that among 144 respondents, 32 women have no property without house and they are been involved with micro credit from 1-10 years. 8 respondents have boat only as assets and among them one is involved for 6-10 years, 3 women are involved between 11-15 years, and 4 women are involved in more than 15 years. 4 respondents have only shop. Among them 2 have involved between 1-5 years, and rest of 2 are involved between 6-10 years. 8 respondents have wood business. Among them 4 are involved within 6-10 years, and another 4 are involved within11-15 years.15 respondent have raw materials business. Among them 4 are engaged within 1-5 years, 7 are involved within 6-10 years and 4 are involved within 11-15 years.8 respondent have rice business where 2 of them are engaged between6-10 years, 2 are involved within 10-15 years and 4 are involved in more than 15 years. 4 respondents have fishing business where one is engaged within 1-5 years, and rest of 3 are involved between 6-10 years. 4 respondents have house and rickshaw. Among them 3 are involved in 1-5 years, and one is involved within 6-10 years.16 respondents have house, cattle and firming land. Among them 5 are engaged in 1-5 years, 7 are involved within 6-10 years, and 4 are involved within10-15 years.15 respondents have house, rickshaw and raw materials business. 2 are 
involved between 6-10 years,7 are involved within 10-15 years and 6 are involved in more than 15 years. 4 respondents have Polli phone business where everyone is involved within 1-56 years.12 respondents have house and polli phone. All of them are involved in 1-5 years. 4 respondents have house and boat. Among them one is engaged in 1-5 years, 2 are involved in 6-10 years and 1 is involved in 10-15 years. 4 respondents have house and cattle where all of them are involved in1-5 years. 4 respondents have house and tractor where everyone is involved in 1-5 years. And finally among others two respondents one is involved in 10-15 years and the second one is involved in more than 15 years. From the above table it is significant that as far as duration of involvement is increasing the numbers of respondents are decreasing.

\section{FINDINGS FROM CASE STUDIES}

Jahanara Begum (Pseudonym, age 26) is the eldest one among the five siblings. She is a widow woman. Her father is late and mother is a paralyzed patient. Her younger sister (second in siblings) is married and two brothers (third and fourth) is doing job in a workshop. And the youngest sister is studying in class six. She and her two brothers earn about 3500-4000 taka per month. But they are to spend about 3000-3500 taka each month. So their family cannot save money. Jahanara went to school up to class three. They have no land for cultivation. They got three decimal lands and a bamboo made house from their father by inheritance. When she asked about the reasoning behind involvement with micro credit, she said, "I got married with Abdul Sattar in 2002. My husband was a rickshaw puller. And unfortunately my husband died in December, 2005 by road accident. I have no children. My husband's family did not accept me cordially and continued rude behave with me. I felt unsecured and returned to my father' family in March, 2006. But the economic situation in my father's family is not good for survival. Then I thought, I have to do something. I took decision to do business. But I had no capital to start business. Few months later, I heard about Grameen Bank activities from my neighboring people. I went to Grameen Bank office and talked with the officers about the system. I joined with Grameen Bank in August 2006. I received 5000 taka loan from Grameen bank and started rice selling business." She explains about her present situation as, "When I started my business, I was not sure that I can do this business. But with the time being my neighboring people know that I am doing rice selling business. I purchase 3 beg rice (150 $\mathrm{kg}$ ) each week at whole sale rate and sell it in my home. I sell at very marginal profit. Even my selling price is lower than local market. For this, many people come to my home. I can give my installment from the profit money. Though sometimes I face problem, but this problem is not regular. So I am in better position than my past." Her perception about micro finance institution like, "I think Grameen bank is good for the poor people. We can get loan easily than the other Banks. But I feel interest rate is little bit higher. And the officers are very strict. They never consider if anybody fails to pay installment. Even sometimes members have to borrow money to pay the installment. After all if anybody can invest the borrowed money, then it brings benefits towards them.

Rubina Begum (pseudonym, age 35) is a divorcee woman. Her husband was a rickshaw puller. She has two daughters and a son. Her first daughter is married and son is doing job in a workshop. Her second daughter reads in class five. She has no house of her own. She lives in a colony where she has to pay 500 taka rent per month. When she was asked for reasoning behind her involvement with Grameen bank, she replied, "I did household work as a servant in neighboring houses. Two years back my husband got second 
marriage and divorced me. Then I fall in serious trouble. I couldn't maintain my family expenses. Few days later I heard about micro credit program from a Grameen Bank member. Then I went to Grameen bank office and took 5000 taka loan to start a tea stall." As she said about her present situation, "now I can maintain my family expenses and I can pay the installment every week from my profit. I give 135 taka per installment on every Sunday. I already paid 27 installments. Now I am planning to take second loan, about 10000 taka to expand my business. I can make profit daily 100-150 taka in average." Her perception about Grameen bank, "I personally happy with Grameen bank. I have very good relation with the field officers of Grameen bank. I regular pay my installments so that the officers do good behave to me. But those who cannot repay the installment, they are to face trouble. Hence, to me, Grameen bank is helpful."

Lokkibala Rani (pseudonym, age 44) is married and her husband Ashim Kumar pal is a fisherman. Lakkibala has two daughters and a son. Her first child Shamoli is married and second child Devu helps his father in fishing. Her third child Anupom is a student of class five. When she was asked for reasoning behind her involvement with Grameen bank, she responds, "I have multiple loans. I took my first loan 5000 taka from BRAC and spent this money on my daughter's marriage. I had no way of income then. For this we couldn't repay the loan. Then I went to Grameen bank and took 5000 taka loan. From this amount, I spent 2000 taka to repay the installments of BRAC and rest of 3000 taka I spent to repair my house." She said about her present condition, "now I am ill. I have chronic back pain. I cannot do any work. My family depends on my husband's income. Though my elder son helps his father but he is very young. Moreover, fishing is seasonal business. Most of the times my husband remains unemployed. So, sometimes I fail to repay the installments of Grameen Bank. Two months back, my husband had suffered by typhoid and I had to spend 2000 taka for his treatment. I was unable to pay the installment for four weeks. Hence my center head Shumita Das and Grameen Bank field officer Harun sir gave pressure on me. But I surrendered that time. I cried and requested them to consider me. And I promised that, I will manage within two weeks. But they did not rely on me. Following the next day, they take away off the sealing (tin made) of my house." Her perception regarding Grameen bank, "I think, the poor people like me have the opportunity to take loan from NGOs like Grameen bank. But those who have daily income source, they get benefits from that. And those who consumed the borrowed money at time like me, they suffered a lot. Though the field officers do misbehave with us, nevertheless we need micro credit program."

The following observations illustrate the emerging concerns about the impact of micro credit on poverty alleviation.

(a) Case studies have shown that borrower have been initially successful but in the long run face a downturn in terms of ownership of asset and level of income.

(b) 69 percent of dropouts resulted from inability to pay installments due to loss in income generating activity.

(c) The older groups and branches of MFIs have higher loan default rate and longer percentage of ineffective groups.

\section{Conclusion AND ReCOMmEndation}

Credit can certainly plays a very important role in the economic empowerment of the poor. But all credit stories are not stories with a happy ending. When credit schemes turn out to be unprofitable, when invested group savings as well as credits have turned into 
costly losses, then the empowerment endeavor turns into its opposite. The landscape of poverty, powerlessness and gender subordination in rural Bangladesh forms the contextual basis for Grameen bank and indeed the micro credit model in Bangladesh. It was also the arena where interventions were easiest for allowing the poor to break out of their cycle of poverty. The conventional banking structure however does not provide access to poor because the poor can provide no collateral and because the overheads required for servicing loans become to high for the small size of loans that poor people requires. Amongst the poor women are even more discriminated against; because patriarchal norms ensure their exclusion from de facto ownership of assets and because the work that women generally engaged at home based productions are not classified as economically productive. The concern with poverty is not only about preventing further decline in welfare, it is also about breaking out of the vicious grip of poverty and making definitive graduation from the vulnerable status. The redeeming feature of micro credit program participation is that even without a significant increase in women's access to resources whose allocation is structurally determined. It is possible to increase access to other choice-expanding but less restricted resources and to enhance the exercise of women's agency, both of which can eventually be effected in transforming the very structures that restrict women's access to resources. In this respect, a long term and sustainable programs strategy would be necessary to promote the expansion of women's access to house hold resources, particularly income generated from loan investment. This is possible if women to be active in decision about loan use and in the control over incomes from loan investment. This is the reason why micro credit is an attractive business for NGOs. Such quick multiplication of credit funds helps the MCIs to sustain and enlarge their operations and prosper. But as seen in this study, micro credit borrowers often fail to break out of income poverty and many even get caught up in an increasing debt-burden syndrome and slide further into poverty. As indicated by the results of the study, not much has happened in relation to women's empowerment through micro credit. Only about 16.75 of the respondents have said that they are in full control of the property run by using the micro credit they take. To recapitulate, the positive impact of the amount of credit on income without a corresponding positive impact of the length of membership indicates the possibility that the successful members continue to obtain credit while the unsuccessful ones drop out or become ineffective members. It is therefore pertinent that future research should focus on the members who drop out or become ineffective members.

\section{REFERENCES}

[1] Ahmed Q.K ( 2007) Socio-Economic and Indebtedness-Related Impact of Micro-Credit in Bangladesh, Dhaka: The University Press Limited.

[2] Ahmed S \& Hakim M. A.(2004) Attacking Poverty with Micro credit, Dhaka: The University Press Limited.

[3] Hamid S. (1996) Why Women Count: Essays on Women in Development in Bangladesh, Dhaka: The University Press Limited.

[4] Holcombe S. H.(!995) Managing to Empower: The Grameen Bank's Experience of Poverty Alleviation, Dhaka: The University Press Limited

[5] Kothari C.R.(1990) Research Methodology: Methods \& Techniques, Second Edition, New Age International Publishers, Delhi, India.

[6] Khandker S. R.(1998) Fighting Poverty with Micro credit: Experience in Bangladesh, Dhaka: The University Press Limited 
[7] Mizan A.N. ( 1994 ) In Quest of Empowerment: The Grameen Bank impact on women's power and status, Dhaka: The University press Limited

[8] Mahmud S. (2001) Assessing Women's Empowerment in the Context of Development: The Case of Micro Credit in Bangladesh, Dhaka: Bangladesh Institute of Development Studies.

[9] Mondal w.(2002) Micro Credit And Micro Entrepreneurship, Dhaka: The Academic Press and PublishersLimited.

[10] Nachmias C.F.(1996)Research Methods in the Social Sciences, Fifth Edition, New York: St. Martin's Press Inc.

[11] Rahman H.Z \& Hussain M.(1995) Rethinking Rural Poverty: Bangladesh as a case study, Dhaka: The University press Limited

[12] Rahman R.I. (2000) Poverty Alleviation and Empowerment Through Microfinance : Two decades of experience in Bangladesh, Dhaka: Bangladesh Institute of Development Studies.

[13] Sen Amartya (1999) On Economic Inequality, Third Edition, Oxford University Press.

[14] Todd Helen (1996) Women at the Center: Grameen Bank Borrowers After one Decade, Dhaka: The University press Limited.

[15] Sahay S. (1998) Women and Empowerment: Approaches and strategies, New Delhi: Discovery publishing House.

[16] Wood G.F. \& Sharif I. (2001) Who Needs Credit? Poverty and Finance in Bangladesh, Dhaka: The University press Limited

[17] Wright G.A.N. (2000) Micro Finance System, Dhaka: The University press Limited.

[18] Yunus Muhammad (1998) Banker to the Poor: The Autobiography of Muhammad Yunus, Dhaka: The University press Limited

[19] Cochran William G.(1990) Sampling techniques, third edition, Wiley eastern limited, India

[20] Kothari C.R. (2005), Research Methodology-Methods and techniques, second edition, New age international limited, India

\section{Appendices}

\section{TABLE1: AgE OF THE RESPONDENTS}

\begin{tabular}{|c|c|c|c|c|}
\hline Age (Years) & Frequency & Percent & Valid Percent & Cumulative Percent \\
\hline $20-24$ & 16 & 11.1 & 11.1 & 11.1 \\
\hline $25-29$ & 12 & 8.3 & 8.3 & 19.4 \\
\hline $30-34$ & 20 & 13.9 & 13.9 & 33.3 \\
\hline $35-39$ & 24 & 16.7 & 16.7 & 50.0 \\
\hline $40-44$ & 8 & 5.6 & 5.6 & 55.6 \\
\hline $45-49$ & 31 & 21.5 & 21.5 & 77.1 \\
\hline $50-54$ & 16 & 11.1 & 11.1 & 88.2 \\
\hline $55+$ & 17 & 11.8 & 11.8 & 100.0 \\
\hline Total & 144 & 100.0 & 100.0 & \\
\hline
\end{tabular}

TABLE 2: MARITAL STATUS OF THE RESPONDENT

\begin{tabular}{|c|c|c|c|c|}
\hline Type & Frequency & Percent & Valid Percent & Cumulative Percent \\
\hline Married & 112 & 77.8 & 77.8 & 77.8 \\
\hline Unmarried & 4 & 2.8 & 2.8 & 80.6 \\
\hline Divorce & 8 & 5.6 & 5.6 & 86.1 \\
\hline Separated & 4 & 2.8 & 2.8 & 88.9 \\
\hline widow & 16 & 11.1 & 11.1 & 100.0 \\
\hline Total & 144 & 100.0 & 100.0 & \\
\hline
\end{tabular}


Table 3: Religion of the respondents

\begin{tabular}{|cc|cc|c|}
\hline Type & Frequency & Percent & Valid Percent & Cumulative Percent \\
\hline Muslim & 120 & 83.3 & 83.3 & 83.3 \\
\hline Hind tuism & 24 & 16.7 & 16.7 & 100.0 \\
\hline Total & 144 & 100.0 & 100.0 & \\
\hline
\end{tabular}

Table 4: Educational qualification of the respondents

\begin{tabular}{|c|c|c|c|c|}
\hline Years of Schooling & Frequency & Percent & Valid Percent & Cumulative Percent \\
\hline 0 & 77 & 53.5 & 53.5 & 53.5 \\
\hline $1-5$ & 36 & 25.0 & 25.0 & 78.5 \\
\hline $6-10$ & 23 & 16.0 & 16.0 & 94.4 \\
\hline $11-12$ & 8 & 5.6 & 5.6 & 100.0 \\
\hline Total & 144 & 100.0 & 100.0 & \\
\hline
\end{tabular}

Table 5: Duration of involvement with micro credit program

\begin{tabular}{|c|c|c|c|c|}
\hline Years & Frequency & Percent & Valid Percent & Cumulative Percent \\
\hline $1-5$ & 69 & 47.9 & 47.9 & 47.9 \\
\hline $6-10$ & 34 & 23.6 & 23.6 & 71.5 \\
\hline $11-15$ & 26 & 18.1 & 18.1 & 89.6 \\
\hline $15+$ & 15 & 10.4 & 10.4 & 100.0 \\
\hline Total & 144 & 100.0 & 100.0 & \\
\hline
\end{tabular}

Table 6: Live in own house

\begin{tabular}{|c|c|c|c|c|}
\hline Type & Frequency & Percent & Valid Percent & Cumulative Percent \\
\hline yes & 128 & 88.9 & 88.9 & 88.9 \\
\hline no & 16 & 11.1 & 11.1 & 100.0 \\
\hline Total & 144 & 100.0 & 100.0 & \\
\hline
\end{tabular}

Table 7: Monthly income of the respondents at present

\begin{tabular}{|c|c|c|c|c|}
\hline Amount (Taka) & Frequency & Percent & Valid Percent & Cumulative Percent \\
\hline $1-2000$ & 16 & 11.1 & 11.1 & 11.1 \\
\hline $2001-4000$ & 42 & 29.2 & 29.2 & 40.3 \\
\hline $4001-6000$ & 60 & 41.7 & 41.7 & 81.9 \\
\hline $6001-8000$ & 8 & 5.6 & 5.6 & 87.5 \\
\hline $8001-10000$ & 16 & 11.1 & 11.1 & 98.6 \\
\hline $10000+$ & 2 & 1.4 & 1.4 & 100.0 \\
\hline Total & 144 & 100.0 & 100.0 & \\
\hline
\end{tabular}

Table 8: Repayment from profit

\begin{tabular}{|c|c|c|c|c|}
\hline Type & Frequency & Percent & Valid Percent & Cumulative Percent \\
\hline yes & 112 & 77.8 & 77.8 & 77.8 \\
\hline no & 32 & 22.2 & 22.2 & 100.0 \\
\hline Total & 144 & 100.0 & 100.0 & \\
\hline
\end{tabular}


Table 9: Using family planning

\begin{tabular}{|c|c|c|c|c|}
\hline & Frequency & Percent & Valid Percent & Cumulative Percent \\
\hline yes & 59 & 41.0 & 41.0 & 41.0 \\
\hline no & 81 & 56.3 & 56.3 & 97.2 \\
\hline n/a & 4 & 2.8 & 2.8 & 100.0 \\
\hline Total & 144 & 100.0 & 100.0 & \\
\hline
\end{tabular}

Table 10: Head of the family

\begin{tabular}{|c|c|c|c|c|}
\hline & Frequency & Percent & Valid Percent & Cumulative Percent \\
\hline Self & 32 & 22.2 & 22.2 & 22.2 \\
\hline Husband & 52 & 36.1 & 36.1 & 58.3 \\
\hline Son & 47 & 32.6 & 32.6 & 91.0 \\
\hline Others & 13 & 9.0 & 9.0 & 100.0 \\
\hline Total & 144 & 100.0 & 100.0 & \\
\hline
\end{tabular}

Table 11: Property looks after

\begin{tabular}{|c|c|c|c|c|}
\hline & Frequency & Percent & Valid Percent & Cumulative Percent \\
\hline Self & 24 & 16.7 & 16.7 & 16.7 \\
\hline Husband & 52 & 36.1 & 36.1 & 52.8 \\
\hline Son & 68 & 47.2 & 47.2 & 100.0 \\
\hline Total & 144 & 100.0 & 100.0 & \\
\hline
\end{tabular}

Table 12: Control over loan/ property

\begin{tabular}{|c|c|c|c|c|}
\hline & Frequency & Percent & Valid Percent & Cumulative Percent \\
\hline self & 24 & 16.7 & 16.7 & 16.7 \\
\hline husband & 52 & 36.1 & 36.1 & 52.8 \\
\hline son & 68 & 47.2 & 47.2 & 100.0 \\
\hline Total & 144 & 100.0 & 100.0 & \\
\hline
\end{tabular}

Table 13: Respondent's perception about micro credit program of Grameen bank

\begin{tabular}{|c|c|c|c|c|}
\hline Type & Frequency & Percent & Valid Percent & Cumulative Percent \\
\hline Satisfactory & 28 & 19.4 & 19.4 & 19.4 \\
\hline Good & 73 & 50.7 & 50.7 & 70.1 \\
\hline Very good & 43 & 29.9 & 29.9 & 100.0 \\
\hline Total & 144 & 100.0 & 100.0 & \\
\hline
\end{tabular}

